Studies in Self-Access Learning Journal

http://sisaljournal.org

\title{
Bringing Learner Self-Regulation Practices Forward
}

Fergus O'Dwyer, Osaka University, Japan

Judith Runnels, University of Bedfordshire, UK

Corresponding author: fodwyerj@gmail.com

Publication date: December, 2014.

\section{To cite this article}

O'Dwyer, F., \& Runnels, J. (2014). Bringing learner self-regulation practices forward. Studies in Self-Access Learning Journal, 5(4), 404-422.

\section{To link to this article}

http://sisaljournal.org/archives/dec14/odwyer_runnels

This article may be used for research, teaching and private study purposes.

Please contact the authors for permission to re-print elsewhere.

Scroll down for article. 


\title{
Bringing Learner Self-Regulation Practices Forward
}

\author{
Fergus O’Dwyer, Osaka University, Japan \\ Judith Runnels, University of Bedfordshire, UK
}

\begin{abstract}
This paper outlines one method through which learner self-regulation can be promoted in CEFR-informed courses using a learning cycle. Previous reports of learning cycles in use have not adequately described how they can be operationalised within the classroom - typically, they have been limited to descriptions of the cycle alone. This paper provides specific examples of how a CEFR-informed learning cycle has been implemented in an EFL process writing class. Cyclical learning and the CEFR as the tools for bringing learner selfregulation practices forward are first introduced. Next, a description of selfregulation practices in the classroom context using the example of an essay writing task in a process writing class is provided. The discussion then focuses on how instructors can encourage learners to carry their self-regulation practices forward to their future learning once a class has been completed. We conclude by suggesting possible benefits of this learning approach, and future directions for research.
\end{abstract}

Keywords: CEFR, self-regulation, learning cycles, action research, process writing

Self-regulation has become an important consideration in language learning (Cohen \& Macaro, 2007; Zimmerman \& Schunk, 2001). Despite a proliferation in publications on language learning strategies and strategy instruction (Oxford, 2013; 1990), classroom teachers remain concerned with how to operationalise such strategies for teaching and learning (Gu, 2013). This paper introduces the process of how self-regulated learning was fostered in Japanese university English majors using learning cycles informed by the Common European Framework of Reference for Languages (CEFR) in the EFL writing classes of one of the authors. The following sections introduce learning cycles and the CEFR, describe how they link together in mobilising learners with the skills they need to self-regulate, and explain how learning cycles have been implemented in a CEFR-informed classroom. 


\section{Self-Regulation Tools: The CEFR, the ELP and the Learning Cycle}

This section introduces the three tools which underpin learner training in self-regulation in the process writing class discussed in this paper: the CEFR, one of its supporting resources, the European Language Portfolio (ELP), and the learning cycle. We are discussing these three tools as we would like readers to understand that in adopting teaching practices intended to promote self-regulation it is not necessary to start from scratch in the development of materials: the CEFR and the ELP, in combination with a learning cycle, provide many, if not most, of the resources and materials that teachers may require to incorporate practices designed to foster learner self-regulation in their own context.

\section{The CEFR and European Language Portfolio}

The CEFR (Council of Europe [COE], 2001) is designed to be an extensive, coherent, and transparent reference system to describe communicative language competences. It has also become an important benchmark with which to align language learning programmes (COE, 2001). Moreover, the CEFR promotes the inclusion of a learning cycle in language learning (among other learning strategies, see Little, 2006) for the purposes of developing the learner's ability to self-regulate (Mariani, 2004).

It functions via a reference grid (COE, 2001) which describes each level of each skill through a descriptor. For example, a B2 Writing descriptor, also known as a can do statement, is as follows: I can write an essay or report, passing on information or giving reasons in support of or against a particular point of view (p. 23). For each language skill at each level (e.g., B2 Writing), the grid is further broken down into the Goal-setting and Self-assessment checklists of can do statements. These checklists provide eight to ten can do statements, which describe each skill level of the CEFR in detail, and which learners can use to target progression on specific levels of the CEFR. The checklists can be found in the appendix of the ELP in English and other European languages. A bilingual English-Japanese version, the Language Portfolio for Japanese University (LP) is also available (FLP SIG, 2009) and was used in the class under discussion in this paper. The ELP is designed to be a reflective implementation tool of the CEFR, and for language learning in general. The pedagogical functions of the ELP are to foster learner autonomy by promoting reflective learning and learner 
responsibility through self-evaluation and goal-setting for language learning (see Little, 2010 and Kühn \& Cavana, 2012 for introductions to the pedagogical implementation of the ELP). Little (2010) suggests that CEFR-informed initiatives are most likely to succeed if generally accepted can do checklists serve as the key reference point for processes of reflective teaching/learning in which self-assessment plays a central role.

\section{The learning cycle}

Learning cycles, which include assessment of and reflection on the achievement of learning goals, can raise learners' awareness about what they may need to focus on in their language learning. While many cycles have been presented in relation to general learning (Kolb, 1984) and learner autonomy (Little \& Perclová, 2001), the four-stage learning cycle in question (originally from O'Dwyer, 2010) differs in its intention by directly linking assigned classroom tasks with learning goals, to generally create a connectedness between teaching and learning in the classroom. The four stages are: Learning Stage Outline; Self-assessment \& Goal-setting; Learning Stage; and Reflection (Figure 1). The implementation of this cycle has been previously explained in depth in relation to task-based language teaching classes (O’Dwyer, Imig \& Nagai, 2014). 


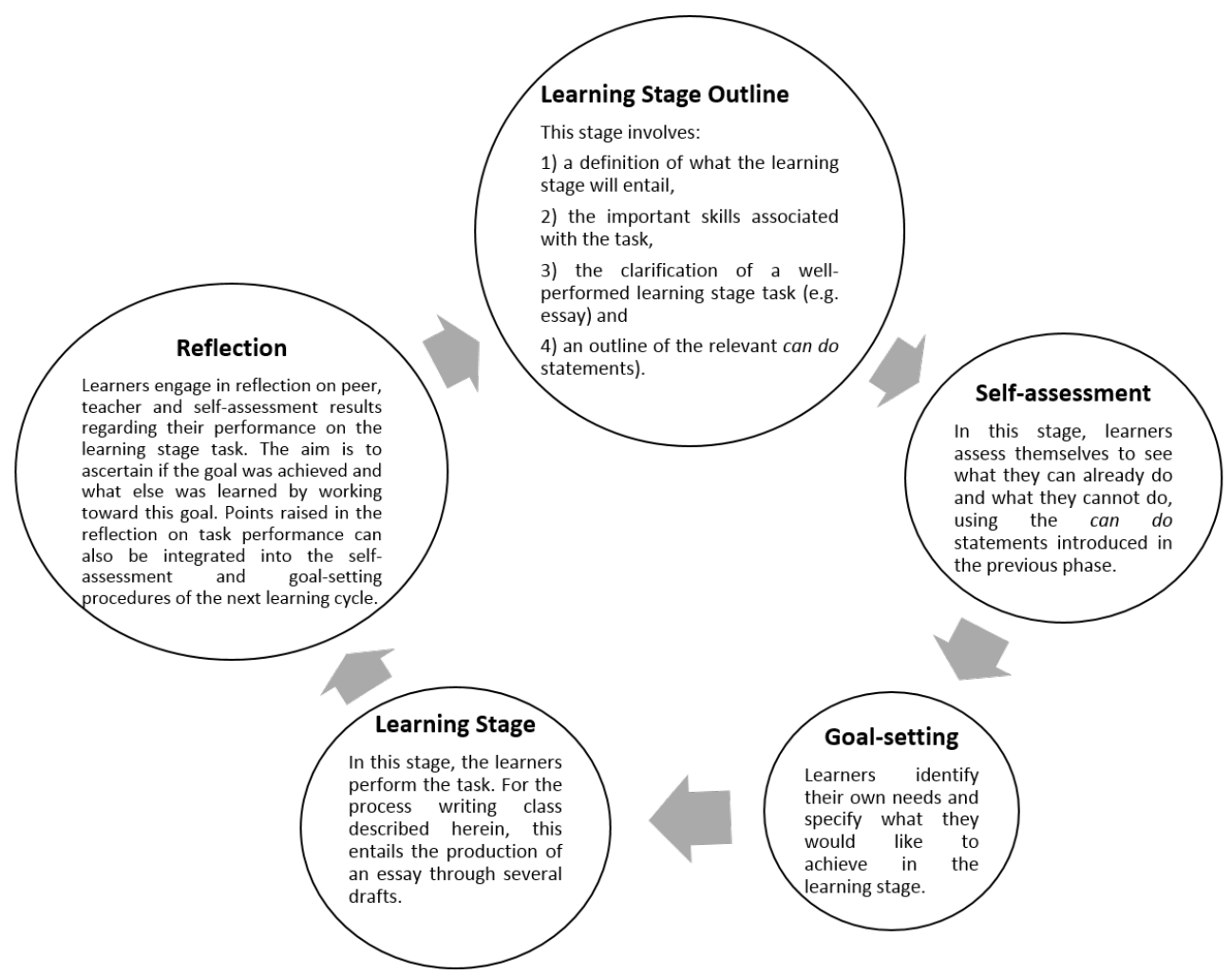

Figure 1. Learning Cycle (modified from O’Dwyer, 2010)

\section{The CEFR and self-regulation}

In the CEFR, language is viewed in an action-oriented way, meaning that the language user or learner must draw upon a variety of both linguistic and nonlinguistic competences to accomplish a task. The CEFR promotes the teaching philosophy of training language learners to behave as social agents and intercultural speakers (Navajas \& Ferrer, 2012) with learner autonomy and selfregulation being developed through class activities and learner training (Lantolf, 2008). Typically, this entails an integration of pedagogical tools and procedures which gradually allow learners to gain control over their learning and eventually develop their abilities in self-regulation. Meanwhile, the teacher gradually reduces the amount of scaffolding the learners can draw from in completing tasks (Monereo, 1995). Esteve (2007) notes that in order to develop self-regulation in learners not accustomed and not expecting to engage in reflection, these habits must be supported by the teacher. One way to foster such habits is with a learning cycle, whose main purpose is to provide a platform for reflective learning informed by the CEFR. The marriage of these two tools is key because "selfregulated learning can only be effective if you know roughly where you are - 
[through] reasonably accurate self-assessment of strengths and weaknesses. This self-assessment will [also] be more accurate if learners are trained to reflect on their progress with the help of descriptors" (North, 2014, p. 110).

The CEFR provides the means by which to estimate ability, thus providing both the starting point of the learning cycle and a direction for future learning. The cycle itself then provides the method by which to train learners in habits that allow them to become more competent at regulating their own learning.

\section{Self-Regulation Practices in Context}

This section outlines both the institutional landscape in which the learners operate, the specific learning context of the writing class, and how the learning cycle, the CEFR and ELP are applied in mobilising learners with the tools and know-how for application in future learning contexts.

\section{The general learning context}

The practices introduced in this paper are from classes taken by English language majors in the School of Foreign Studies, Faculty of Language and Culture in Osaka University, Osaka, Japan. The achievement goals from the first to the fourth year for all twenty-five languages taught in this school are based on the common reference levels of the CEFR. For the English majors, the achievement goals for each skill for the end of the first, second, and fourth years correspond to the global scales of the CEFR for all five language skills (for listening, reading and writing, the general target is to progress to B2 in the first year, to $\mathrm{C} 1$ in the second year, and to $\mathrm{C} 2$ in the fourth year, and for spoken interaction and spoken production the general target is to progress to B2 in the second year, and to $\mathrm{C} 1$ in the fourth year). The learners have seven English classes in the first year (three classes focusing on spoken interaction and spoken production, and four reading- and writing-focused classes) and five in the second year (three classes focusing on spoken interaction, spoken production, and writing, and two reading and integrated skills classes).

\section{Self-assessment as a departure point of the learning cycle}

In their first year of study, learners engage in a number of practices all with the implicit and ultimate goal of encouraging learner self-regulation. These 
include having the learners think about their aims and reflect on their strengths and weaknesses, reflect on and record the ways they learn best, and describe different learning approaches for different purposes. For instance, in a speakingfocused first year class, learners use an online self-assessment computer program three to four times a semester to self-assess their ability to perform the can do statements of the CEFR and the LP (see Smith, 2012 for an overview of this process). The can do statements for each skill are those from the Goal-setting and Self-assessment checklists (FLP SIG, 2009). As these checklists elaborate on each skill level of the CEFR, it is possible to observe minor improvements in learning. Through their first year classes, it is expected that the learners will become accustomed to engaging in self-assessment and working within the framework of the CEFR with the hope that learners are able to identify the starting point from which a learning cycle can commence (North, 2014). It is not until their second year that the learners are introduced to the learning cycle in the process writing class described below.

\section{The specific learning context: A CEFR-informed process writing class}

Process writing is an approach to essay writing that encourages writers to plan and revise, rearrange and delete text, re-read and produce multiple drafts before they produce their finished document (Stanley, 2003). The general goal of the writing class is for the students to progress to the point where they are able to write well-structured essays of around 1,000 words that "underline the relevant salient issues, expanding and supporting points of view at some length with subsidiary points, reasons and relevant examples, and rounding off with an appropriate conclusion" (COE, 2001, p. 61). The students themselves focus on a single B2 Writing can do statement (taken from the LP) for the entire academic year: I can write an essay or report, which develops an argument, giving reasons to support or negate a point of view and weighing pros and cons. Although the majority of learners are estimated to be around an upper B1 or lower B2 level at the outset of the class, in order to accommodate a range of learning competences, the B2 can do statement above is scaled, accommodating the two following can do statements from $\mathrm{B} 1$ and $\mathrm{C} 1$ respectively: 
B1: I can write straightforward connected texts and simple essays on familiar subjects within my field, by linking a series of shorter or discrete elements into a linear sequence, and using dictionaries and reference resources.

C1: I can write clear, well-structured texts on complex subjects in my field, underlining the relevant salient issues, expanding and supporting points of view at some length with subsidiary points, reasons and relevant examples, and rounding off with an appropriate conclusion.

The skills relevant to achieving these competences are addressed in sixty 90 minute classes over two semesters throughout which students produce six essays. The teacher uses tasks from a CEFR-informed process writing textbook for the first five essays (Zemack \& Stafford-Yilmaz, 2008). The content of the first five essays and their associated can do statement are shown in Figure 2. The sixth essay is a free essay, in which the students make their own decisions about the type of essay and its content.

\begin{tabular}{ll}
\hline Essay Number and Type & Can do statement \\
\hline 1: Explanatory & $\begin{array}{l}\text { I can write an essay highlighting the significance of people, events, experiences, etc., fully } \\
\text { explaining the points I feel are important. }\end{array}$ \\
\hline 2: Problem-Solution & $\begin{array}{l}\text { I can write an essay which outlines a problem and develops a solution, giving reasons to support } \\
\text { my point of view. }\end{array}$ \\
3: Compare-Contrast & $\begin{array}{l}\text { I can write an essay that compares and contrasts alternatives, fully explaining points of } \\
\text { significance in a detailed and easily readable way. }\end{array}$ \\
4: Persuasive & $\begin{array}{l}\text { I can write a persuasive essay which develops my arguments, counters likely opposing arguments } \\
\text { and convinces the reader of my point of view. }\end{array}$ \\
5: Responding to a reading & $\begin{array}{l}\text { I can write clear, well-structured responses to texts, underlining the salient issues, expanding and } \\
\text { supporting my point of view, providing reasons and relevant examples, and rounding off with an } \\
\text { appropriate conclusion. }\end{array}$ \\
\hline
\end{tabular}

Figure 2. Contextualised Can Do Statements for Each Essay Assigned in the

\section{Process Writing Class}

\section{The learning cycle in practice: From reflection to self-assessment}

Each learning cycle both starts and ends with reflection. After receiving teacher feedback following the completion of any essay, learners enter the reflection stage. In the reflection stage, learners discuss with their peers assessment criteria and feedback related to the essay they just completed, the relevant can do statements of that essay (Figure 2), a series of questions provided from the instructor (such as "What have I done well? What could I improve?") as well as reflective questions specific to the content of the previous essay. These 
discussions lead to the creation of a list which will be used in the goal-setting stage of the upcoming essay. Typically, the list highlights the areas in which the learner feels they are doing well or need to improve. Added to this list are the can do statements for the upcoming essay (either from the LP writing checklist or the relevant chapter in the textbook).

The learners then enter the learning stage outline stage where the teacher introduces their task for the upcoming essay, adding any relevant items to the list. Subsequently, the learners enter the self-assessment stage of the learning cycle and self-assess on each of the list's items. Due to their self-assessment training in their first year of study, the learners generally appear to be comfortable and relatively accurate in performing this kind of a self-assessment. To summarise the steps so far, Figure 3 provides an example of how the learners progress from the completion of essay 3 to the commencement of essay 4 .

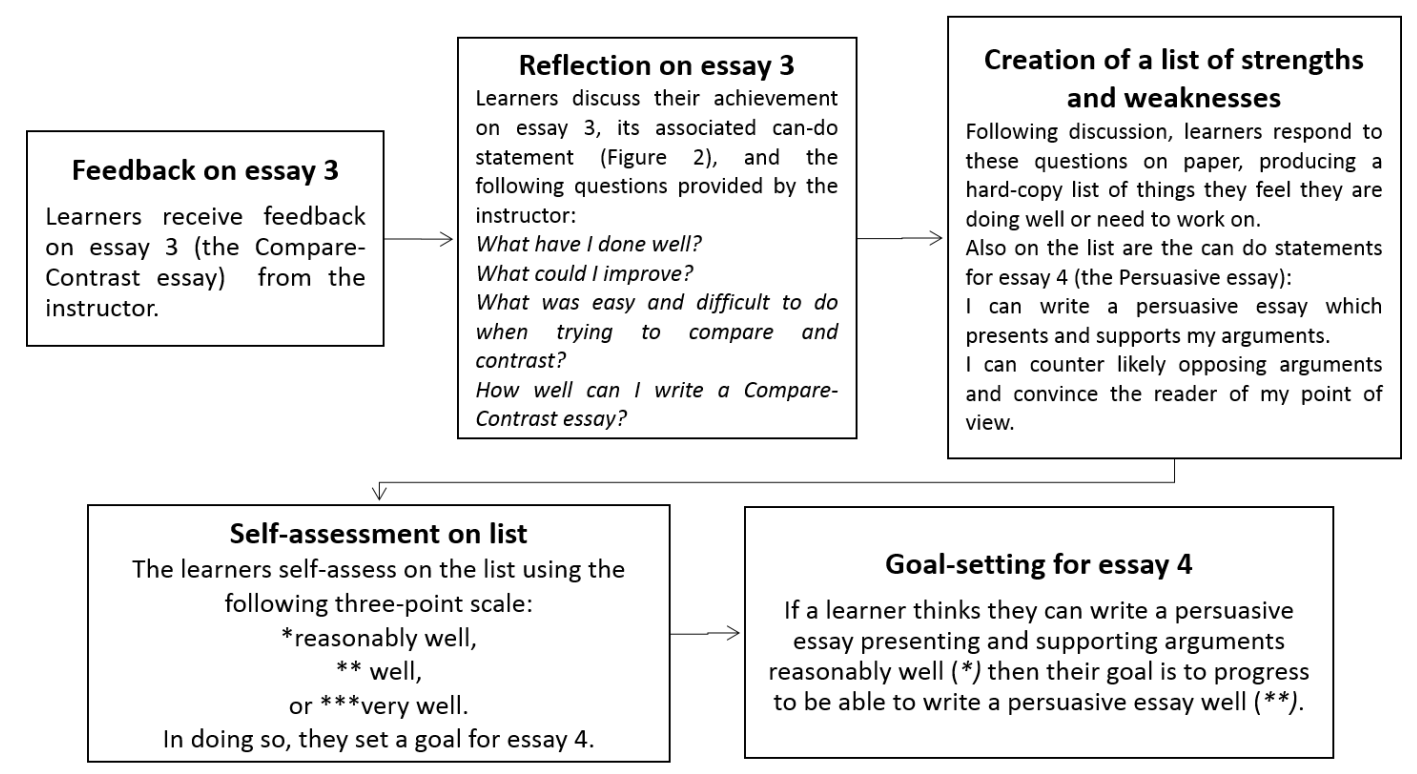

Figure 3. The Steps Taken by Learners from the Reflection Stage of Essay 3 to the Learning Stage of Essay 4

\section{The learning cycle in practice: Goal-setting}

As shown in Figure 3, the results of the self-assessment provide the starting point for the goal-setting. The teacher of this course uses a three point scale for self-assessment (although any scale seen to be appropriate could be employed). Essentially, the learner's goal is to progress one point up in the scale 
for each item on the list during the writing of the next essay. In addition to the list created from reflection on the previous essay, the instructor also uses the 'My next language learning target' sheet on page 10 of the LP (Appendix A) as the second part of the goal-setting. The instructor fills in some relevant information (e.g., what learning materials are needed and how the classes will generally proceed) and gives this to the learners, asking them to fill in the remainder of the sheet by setting clear and achievable goals for themselves. In order for learners to be able to monitor progress during the learning stage, they need to be able to refer to the relevant criteria provided by this sheet. Learners may additionally set their own criteria (marked by a $\star$ in Appendix A) based on strengths and weaknesses that emerged from reflection on any previous essay. In this way, both their goals and the assessment criteria under which they will produce the essay are individualised.

Following the goal-setting on an individual student basis, the final step in the goal-setting stage is to work with the class in developing an assessment rubric. The instructor poses the class oral questions regarding what elements they might expect to see in a persuasive or a problem-solution essay. These elements can relate to the structure, the style or the content of the essay. The class first discusses in groups, and then brainstorms together various ideas which are compiled in an assessment rubric (an example of which is shown in Appendix B) to be used for assessing what is produced in the learning stage. This rubric can be used for self-assessing the essay at any stage of the writing process, for peer assessment of drafts of the essay, plus teacher assessment of the final versions of the essay. It also provides additional guidelines that the learners should keep in mind throughout the writing process. Figure 4 shows examples of questions that might be asked by the instructor for essay 4 and the answers provided by learners.

\begin{tabular}{ll}
\hline Instructor questions for essay $\mathbf{4}$ & Sample student responses \\
\hline 1. What are the elements of a good persuasive essay? & $\begin{array}{l}\text { The thesis statement is clear and easy to } \\
\text { understand. }\end{array}$ \\
\hline $\begin{array}{l}\text { 2. How can I fully support the points of significance } \\
\text { in a detailed and easily readable way? }\end{array}$ & $\begin{array}{l}\text { Use paragraphs for each point of } \\
\text { significance. }\end{array}$ \\
\hline 3. How can I convince the reader? & Provide reasons for each argument. \\
\hline
\end{tabular}

Figure 4. Questions Asked by the Instructor and Sample Student Responses for Inclusion on an Assessment Rubric 
In general, these assessment practices follow the principles of learningoriented assessment (LOA), which generally promote a positive classroom assessment culture (Carless, 2009). In a LOA view, students should actively engage with transparent assessment criteria (e.g., in the case of writing an essay, what makes an effective essay), and assessment quality (e.g., the quality of explanations and information provided in an essay).

\section{The learning cycle in practice: The learning stage}

The learning stage cycle typically spans about four classes per essay. Following the goal-setting, the teacher typically assigns learners with the homework task of developing a topic and some ideas on the topic to form the basis of the essay. For example, in the case of essay 4, the persuasive essay, this homework entails the learners selecting their overall argument and three main supportive arguments. The learners discuss their ideas with their peers, who provide critical and reflective feedback, possibly referring to the goal-setting documents. The next major homework assignment is for the learners to write their first draft, bringing a printed version of it to the following week's class, where a similar process is carried out. The learners first discuss their first drafts, get oral feedback from peers, read their peers' essays and provide oral or written feedback on the actual draft. The teacher then draws attention to specific aspects of the assessment criteria, or sections from the textbook for the learners to offer each other comments on. This occurs for a second and third draft before the learners submit their essays to the teacher for formal assessment and the process returns to the reflection stage leading into the fifth essay. It should also be noted that any feedback from the teacher should be timely and forward-looking so as to support current and future student learning: in other words, feedback should focus learners toward improvement in current and future learning tasks (Carless, 2009).

\section{The final cycle and beyond}

Towards the end of the course more control is expected from the learners. For the fifth essay of the year, the process differs slightly, with the variation beginning in the goal-setting stage. In the case of the fifth and sixth essays only, learners are not provided a can do statement, but are encouraged to complete a blank 'My next language learning target' sheet (Appendix A). For the final 
(sixth) essay, the students lead the process entirely on their own and are not provided with any resources, but are welcome to draw on resources they have been given throughout the year. They can formulate the goals in accordance with any can do statement from the textbook or the LP Writing checklist, and the type of essay they choose to write.

\section{After the process writing class}

At the end of the class, learners receive a handout which makes suggestions as to where and how they can implement the practices they have acquired more independently. Following minor instruction on this topic, the learners discuss integrating the learning cycle in their future learning contexts and how to bring their self-regulated practices forward. Following the process writing class, and the second academic year in general, the students are expected to be familiar with how to self-assess (from their first year training), and be armed with the general knowledge required for implementing a learning cycle in any learning context. The final essay of the second year is a good test for this, as they are expected to make all of the decisions in the production of their essay. This increase in control continues in their third year courses, culminating in Content Language and Integrated Learning (CLIL) classes, which typically involve individual study projects that incorporate English academic content. In these courses, since the focus is on more independent learning with less teacher guidance, the specific content of the self-assessment and formal assessment tools is adjusted continually and concurrently by both learners and instructors.

\section{Discussion}

The combination of cyclical learning (Figure 1), learning-oriented assessment (Carless, 2009) and classroom implementation of the CEFR can create pedagogical synergy, a positive classroom assessment culture, and may help learners act independently (O’Dwyer, Imig \& Nagai, 2014). In the writing class described, although initially the teacher had the greatest responsibility in leading the learners through the learning cycles, more and more control was relinquished each time a subsequent cycle was undertaken. By the end of the course, the learners took full control of the essay writing process, selecting their topic, 
creating their self-assessment lists, performing their own goal-setting and determining the assessment criteria for their essay. At the end of the course, materials for how these practices could be brought forward for different classes in the learners' third and fourth years of study were provided and then discussed. Providing resources that can apply to future learning at the end of a course represents one way to foster self-regulation.

\section{Future research}

While the pedagogical practices described herein are believed to allow learners to begin to operate autonomously, the authors admit that many assumptions are made about the learners' capabilities in engaging with the processes within each stage of the learning cycle. Basic comments from the learners about these processes (obtained via a student feedback survey) included that the "learning cycle can be used in any learning situation" and that the learners were happy to receive "direct feedback from classmates and the teacher that helps to improve my writing." Nonetheless, further research is certainly required to address whether the learners found self-assessment to be straight-forward and useful and were not just randomly selecting one of the options-well(*), reasonably well(**), or very well(***) — on the self-assessment tasks assigned to them by the teacher. Additionally, whether learners achieved the goals they set in the goal-setting stage, how they determined they had or had not achieved them, and the degree to which they benefited and learnt from reflection should also be examined. Furthermore, since class time was devoted to brainstorming an assessment rubric, investigation as to whether this brainstorming process, or the rubric itself, aided the writing process in the learning stage, or contributed to the achievement of goals would provide some insight on whether its usage was achieving the purpose for which it was intended. Finally, the learners' experience in navigating the learning cycle involved in the production of the final free essay and the extent to which the learning cycle is employed following the completion of the class would be worth investigating in order to provide some evidence for the degree to which self-regulation is internalised. At this point, there is no empirical evidence to support the extent to which self-regulation was fostered within each individual student. Overall, the functioning and efficacy of the CEFR- 
informed learning cycle presented herein would benefit greatly from learner feedback at every stage of the cycle, at the conclusion of the course, and even following completion of the course or the degree programme.

Nonetheless, it is believed that placing the can do statements of the CEFR and ELP in the centre of self-regulation practices enables the CEFR's recognised benchmarks to be incorporated by the students into their future learning contexts. It is also thought that incorporating the CEFR and ELP into a learning cycle arms learners with sufficient knowledge and know-how for them to be capable of engaging in self-regulated learning behaviours, regardless of what teaching styles and programmes they encounter.

\section{Notes on the contributors}

Fergus O'Dwyer is an associate professor at Osaka University. His interests include the use of the CEFR, learner autonomy and sociolinguistics.

Judith Runnels is a research graduate student at the University of Bedfordshire. Her research interests include program evaluation, language testing and usage of the CEFR by language teachers.

\section{References}

Carless, D. (2009). Learning-oriented assessment: Principles, practice and a project. In L. H. Meyer, S. Davidson, H. Anderson, R. B. Fletcher, P. M. Johnston, and M. Rees (Eds.), Tertiary assessment \& higher education student outcomes: Policy, practice \& research (pp. 79-90). Wellington, New Zealand: Ako Aotearoa.

Cohen, A., \& Macaro, E. (Eds.) (2007). Language learner strategies: Thirty years of research and practice. Oxford, UK: Oxford University Press.

Council of Europe (2001). The Common European Framework of Reference for Languages: Learning, teaching, assessment. Retrieved from http://www.coe.int/t/dg4/linguistic/Source/Framework_EN.pdf

Esteve, O. (2007). Interaction in the classroom [Video file]. Retrieved from: http://www.edu3.cat/Edu3tv/Fitxa?p_id=23236

Framework \& Language Portfolio SIG (2009) Language Portfolio for Japanese University. Retrieved from https://sites.google.com/site/flpsig/flp-sighome/language-portfolio-for-japanese-university 
Gu, M. (2013). [Review of the book Curriculum reform in China: Changes and challenges, by H-B. Yin \& J. C-K. Lee (Eds.)]. Frontiers of Education in China, 8(4), 631-634. doi:10.3868/s110-002-013-0041-3

Kolb, D. A. (1984). Experiential learning. Experience as the source of learning and development. Englewood Cliffs, NJ: Prentice-Hall.

Kühn, B., \& Cavana, M. L. P. (Eds.). (2012). Perspectives from the European Language Portfolio: Learner autonomy and self-assessment. London, UK: Routledge.

Lantolf, J. P. (2008). Praxis and classroom L2 development. Estudios de Linguistica Inglesa Aplicada, 8, 13-44.

Little, D. (2006). The Common European Framework of Reference for Languages: Content, purpose, origin, reception and impact. Language Teaching, 39(3), 167-190. doi:10.1017/S0261444806003557

Little, D. (2010). The European Language Portfolio and self-assessment: Using "I can" checklists to plan, monitor and evaluate language learning. In M. G. Schmidt, N. Naganuma, F. O’Dwyer, A. Imig, \& K. Sakai (Eds.), Can do statements in language education in Japan and beyond (pp. 157-66). Tokyo, Japan: Asahi Press.

Little, D., \& Perclová, R. (2001).The European Language Portfolio: A guide for teachers and teacher trainers. Strasbourg, France: COE. Retrieved from http://www.coe.int/T/DG4/Portfolio/?L=E\&M=/main_pages/documents.ht $\underline{\mathrm{ml}}$

Lockhart, C. (1994). Reflective teaching in second language classrooms. Cambridge, UK: Cambridge University Press.

Mariani, L. (2004). Learning to learn with the CEF. In K. Morrow (Ed.), Insights from the Common European Framework (pp. 32-42). Oxford, UK: Oxford University Press.

Monereo, C. (1995). Teaching consciousness: Towards a metacognitive teaching? Aula, 34, 74-80.

Navajas, A., \& Ferrer, A. (2012). Using SCOBAs to help learners develop selfregulation. Frontiers of Language and Teaching, 3, 239-247.

North, B. (2014). The CEFR in practice. Cambridge, UK: Cambridge University Press.

O'Dwyer, F. (2010). Can do statements at the centre of involving learners in the self-assessment, goal-setting and reflection learning cycle. In M. G.

Schmidt, N. Naganuma, F. O’Dwyer, A. Imig, \& K. Sakai (Eds.), Can do 
statements in language education in Japan and beyond (pp. 218-234). Tokyo, Japan: Asahi Press.

O’Dwyer, F., Imig, A., \& Nagai, N. (2014). Connectedness through a strong form of TBLT, classroom implementation of the CEFR, cyclical learning, and learning-oriented assessment. Language Learning in Higher Education, $3(2), 231-53$.

Oxford, R. L. (1990) Language learning strategies: What every teacher should know. Boston, MA: Heinle and Heinle/Cengage.

Oxford, R. L. (2013). Teaching \& researching: Language learning strategies. London, UK: Routledge.

Smith, A. F. (2012) Progressive adaptive learning assistant-PALA, and what she can do for teachers, learners and curriculum planners and administrators in language programs using the Common European Framework. Journal of Anglo-American Studies, 35, 112-40.

Stanley, G. (2003). Approaches to process writing. Barcelona, Spain: British Council. Retrieved from http://www.teachingenglish.org.uk/article/approaches-process-writing

Zemack, D., \& Stafford-Yilmaz, L. (2008). Writers at work: The essay student's book. Cambridge, UK: Cambridge University Press.

Zimmerman, B. J., \& Schunk, D. (Eds.). (2001). Self-regulated learning and academic achievement ( $2^{\text {nd }}$ ed.). Mahwah, NJ: Erlbaum. 


\title{
Appendices
}

\author{
Appendix A My Next Language Learning Target
}

\section{My next language learning target}

Here you can write down your next learning target and record your progress in achieving it. When setting learning targets, you can use the goal setting and self-assessment checklists in the appendix to formulate your learning target.

\begin{tabular}{l} 
Language: English \\
\hline Learning Target学習目標 \\
(Use the Self-assessment grid in the Language Passport and the checklists in the \\
appendix to formulate your next language learning target as precisely as possible言語パ \\
スポートの自己評価表と付録のチェックリストを用いて、次の目標をできるだ \\
け詳細に立てる)
\end{tabular}

October Writing goal: I can write a persuasive essay which develops my arguments.

$\{*$ reasonably well $\rightarrow * *$ well $\} \quad\{* *$ well $\rightarrow * * *$ very well $\}$

I can counter likely opposing arguments and convince the reader of my point of view.

$\{*$ reasonably well $\rightarrow * *$ well $\} \quad\{* *$ well $\rightarrow * * *$ very well $\}$

How much time can I devote each day/week to achieving my target?

目標達成のために1日または1週間でどのくらいの時間を費やすことができる か?

2 to (? ?) hours a week

When shall I begin? いつから始 When do I plan to finish? いつ終えるか？

めるか?

Early November

October $3^{\text {rd }}$

How do I intend to achieve my target? 目標達成をどのようにめざすか？

For example, can I work alone or do I need to work with other people? 例えば、一人で 学習するのか、他の人と一緒に学習するのか?

Complete Chapter 4 activities: - Brainstorm and discuss about a controversial, topical theme. Write a persuasive essay which presents and supports my arguments. The essay will need to counter likely opposing arguments and convince the reader of my point of view. My own criteria:

What learning materials do I need? どのような教材が必要か?

Writers at work Textbook, Language Portfolio \& ---

How shall I know whether or not I have achieved my target? 目標に到達した か、あるいはしなかったかをどのように知るか? (For example, can I take a test or set and correct a test myself? Or shall I need to ask my teacher, another learner, or a native speaker to assess me? Or can I depend entirely on my own judgement? 例え ば、テストを受けるのか、自分でテストを作って解答するのか? 先生に聞くの か、他の学習者やネイティブに評価をしてもらうのか? 完全に自分の判断に任 せるのか?）

Refer to self-peer-teacher assessment of the essay both in the first, second and final drafts of the essay. I should be able to provide convincing arguments which are not easily dismissed. 


\section{$\star$ My own criteria:}

Review of learning progress on or near my target date学習経過や直近の目標日 程の振り返り

Have I achieved my target? In working toward my target have I learnt anything new about (i) the target language (ii) language learning? What am I going to do with what I have learned? 目標を達成したか? 目標に向かう中で(i)目指す言語、(ii)言語学習 について新しいことを学んだか?これまで学んだことを今後じういかすのか? 


\section{Appendix B Feedback Form}

\section{Persuasive Essay Feedback}

\section{A. Topic and introduction}

The topic is easy to understand, familiar, engaging, and controversial There is a unique and engaging hook. The background is sufficient. The thesis statement contains a strong opinion about the topic with a course of action suggested

\section{5}

B. Main body paragraphs: Arguments

Each body paragraph has one clear argument which is fully developed with sufficient information.

These main arguments are well organised and are supported appropriately and thoroughly.

The support is appealing and effective; it comes from actual experience and/or relevant research. Statistics are used appropriately.

\section{5}

C. Main body paragraphs: convincing?

The arguments are clear, strong, logical, and explained in detail.

Likely counterarguments are accounted for effectively.

The main arguments convince the reader to the writer's point of view.

\section{5}

\section{Conclusion/Overall}

The conclusion summarizes the arguments and finishes with a powerful concluding statement

Various types of support are used appropriately; transitions and modals are used where necessary.

In general the essay is balanced and well constructed.

\section{5}

Total: $/ 20$

E. You can write a persuasive essay which develops your arguments fully.

\section{*reasonably well,** well, *very well}

You can counter likely opposing arguments and convince the reader of your point 
SiSAL Journal Vol. 5, No. 4, December 2014, 404-422

\begin{tabular}{l} 
of view. \\
$\qquad$ reasonably well, $* *$ well, $* * *$ very well \\
F. General and other comments and advice: \\
\hline
\end{tabular}

